\title{
Repercussions of teenage pregnancy in the life of adult women
}

\author{
Repercussões da gravidez na adolescência na vida da mulher adulta
}

Patrícia Mattos Monteiro Dias ${ }^{1}$, Jocélia Maria de Oliveira ${ }^{1}$, Amanda Peres Lustosa ${ }^{2}$, Hana Klébia Leonel da Silva Lima $^{2}$, Karla de Abreu Peixoto Moreira ${ }^{1}$, Thayza Miranda Pereira ${ }^{2}$

Objective: to uncover the repercussions of pregnancy during adolescence on the life of women in adulthood. Methods: a qualitative study performed in a Basic Health Unit. Individual data were collected and recorded with seven women for data collection. For the organization of the data, the Thematic Categories Analysis was adopted. Results: three categories emerged: recalling the experiences of pregnancy in adolescence, positive and negative repercussions of teenage pregnancy in the view of women and rescuing knowledge about contraceptive methods in adolescence. Conclusion: the pregnancy occurred in adolescence had positive repercussions when reporting the development of responsibility and maturity, the constitution of a family, and being a mother. As for the negative aspects, the following were observed: the non-completion of the studies; fear of having another child; responsibility; difficulty in reaching plans for the future.

Descriptors: Adolescent Health; Pregnancy in Adolescence; Women’s Health.

Objetivo: desvelar as repercussões da gravidez ocorrida na adolescência para a vida da mulher na idade adulta. Métodos: estudo qualitativo realizado em uma Unidade Básica de Saúde. Para coleta de dados, foram realizadas entrevistas individuais e gravadas com sete mulheres. Para organização dos dados, adotou-se a Análise de Categorias Temáticas. Resultados: emergiram três categorias: Recordando as vivências da gravidez na adolescência, Repercussões positivas e negativas da gravidez na adolescência na visão das mulheres e Resgatando conhecimentos sobre os métodos contraceptivos na adolescência. Conclusão: a gravidez ocorrida na adolescência repercutiu de forma positiva quando relatado o desenvolvimento da responsabilidade e da maturidade, constituição de uma família, e ser mãe. Quanto aos aspectos negativos a não conclusão dos estudos; medo de ter outro filho; responsabilidade; dificuldade no alcance de planos para o futuro.

Descritores: Saúde do Adolescente; Gravidez na Adolescência; Saúde da Mulher.

\footnotetext{
${ }^{1}$ Maternidade Escola Assis Chateaubriand. Fortaleza, CE, Brazil.

${ }^{2}$ Escola de Saúde Pública do Ceará. Fortaleza, CE, Brazil.

Corresponding author: Patrícia Mattos Monteiro Dias

Rua Sátiro Dias, 535, Montese, CEP: 60420-430. Fortaleza, CE, Brazil. E-mail:patinhamatos@gmail.com
} 


\section{Introduction}

Adolescence is a period of transition of great importance in a person's life, entails several changes in his physical, social and psychic state, which can lead adolescents to face conflicts and crises. It is a phase of intense changes, which the adolescent needs to live healthily so that it adequately reaches its bio-psychosocial maturity ${ }^{(1)}$. Estimated data for 2016 of the resident population in Brazil was 206,081,432 of which 51.3 million were teenagers aged 10 to $19^{(2)}$.

The adolescent presents behavioral changes that can lead him to exercise inconsequently his sexuality, generating numerous conflicts and interfering in his plans for the future. As a result of this situation, early pregnancy, abortion, sexually transmitted infections, acquired immunodeficiency syndrome, school drop-out and marginality can be cited among others ${ }^{(3)}$.

Comparison of the 2000 and 2010 Census data with regard to the pregnancy of young people shows that the proportion of women aged 15-19 with at least one live birth child decreased from $14.8 \%$ in 2000 to $11.8 \%$ in 2010 . However, this indicator showed that most of the municipalities in the North, Northeast and Center-West regions, besides Paraná, presented values higher than the national average $\mathrm{e}^{(4)}$.

In the year $2014,18.8 \%$ of live births in Brazil were the children of adolescents aged 10 to $19^{(5)}$. Thus, teenage pregnancy is a public social and health problem, representing a challenge for the multi-professional team and bringing biological, social and emotional consequences to the adolescent ${ }^{(6)}$.

Although teenage pregnancy is a theme widely studied in the literature, there are few studies that reveal the repercussions of the pregnancy that occurred in adolescence for the life of the woman, as an adult. It is believed that such disclosure may help to answer concerns about the woman's perception of the experience of having a teenage pregnancy, the repercussions of teenage pregnancy on the life of the woman in adulthood, as well as the knowledge about the con- traceptive methods that supported their decisions at the time.

Thus, the adult woman who experienced teenage pregnancy was delineated as the object of the study. It is believed that the results of this study may contribute to the knowledge of factors related to a pregnancy that occurred during the adolescence and that permeate the long term in the life of the woman and her perception of having experienced such experience, thus defined as objective to unveil the repercussions of pregnancy during adolescence on the life of women in adulthood.

\section{Methods}

It is a qualitative study, which aims at involving the collection of data at a specific time and describes a situation or phenomenon at a given time ${ }^{(7)}$.

The study was developed in a Basic Health Unit of a county, $40 \mathrm{~km}$ away from Fortaleza the capital of the State of Ceará, northeastern region of Brazil.

The inclusion criteria were: having had the first live child in adolescence, understood in this study as the period from 10 to 19 years; and belong to the micro area of responsibility of the authors of the research, because the subject-researcher link could facilitate the exploration of the lines during the interview. The refusal to participate in the study was adopted as an exclusion criterion. However, it should be noted that there was no exclusion of participants.

The subjects of the study were seven women, with current age between 25 and 35 years. This age group was chosen to capture women who experienced teenage pregnancy not long ago, and it is possible to have detailed memories of the experience.

The number of women was determined together with the collaboration of the Community Health Agent of the micro area under their responsibility, according to the inclusion criteria described, within the two-month period of data collection. The Community Health Agent provided the contact of the women who 
had the desired profile for the study. The interview was scheduled by the researchers through telephone contact, directly with the woman participating in the study, and held in the place of preference of the same.

The data were collected in the period of April and May of 2015. For data collection, a semi-structured interview script was used composed of open and closed questions. During the data collection, the saturation criterion of the women's speech was applied to the sample definition. Thus, seven interviews were required. The study starting question was "What the experience of having experienced pregnancy in adolescence brought to life today?" The saturation criterion is described when the data collection is interrupted when it is found that new elements to subsidize the desired theorization are no longer understood from the field of observation ${ }^{(8)}$.

The interviews were recorded with the consent of the women participating in the research. The field diary was used to record the process of approaching the field, the positive experiences as well as the possible difficulties for carrying out fieldwork.

For the organization of the data, the Thematic Categories Analysis was adopted, whose stages involve: information preparation; unitarization or transformation of the content into units; categorization or classification of units into categories; description and interpretation ${ }^{(9)}$.

The material resulting from the interviews was heard, transcribed and read, exhaustively, for categorization. In order to guarantee the confidentiality of the names of the women involved in the research, flower names were assigned to each one, the name of the flower being chosen according to the first letter of the initial of the interviewee's name.

The study complied with the formal requirements contained in the national and international regulatory standards for research involving human beings.

\section{Results}

Regarding the socio-demographic characteristics, all seven women considered themselves to be colored. Concerning the current marital status and number of children, four were married to the same partner of the teenage period. With the exception of one mother, six women had more than one child. It is worth mentioning that this mother chose to become pregnant only once due to the experience lived during her delivery.

Regarding schooling, it was observed that three women had high school education and four had incomplete elementary education, none of which was in technical or higher education. As for the occupation, two women had informal employment and five were housewives. The predominant family income was 1 to 3 minimum wages.

After all the statements were transcribed in full, they were read again and again in order to separate the excerpts that responded to the study objective. From the interviewees' statements, three categories emerged: recalling the experiences of pregnancy in adolescence, positive and negative repercussions of teenage pregnancy on the view of women and rescuing knowledge about contraceptive methods in adolescence.

\section{Recalling the experiences of pregnancy in adoles- cence}

When women were asked to speak about the experience of having had a teenage pregnancy, the factors that facilitated them and others that made it difficult to go through that moment in their lives emerged from the statements.

The facilitating factors were presented in a smaller number and were the support of family members and/or friends, fulfilling a dream, as can be seen 
in the excerpts: ...We were gradually discovering it was not so difficult to live with; my mother always supported me, my mother-in-law, too. What we did not know, was always talking, was always showing what it was, supporting, which was more certain (Lavander). The colleagues supported me in everything (Salvia).They supported me (the parents), even because he (the boyfriend) was a hardworking person (Acacia). I wanted to, I wanted to get pregnant because my dream was to have a child (Jasmin).

Factors that hindered the experience of having gone through teenage pregnancy appeared in greater numbers and referred to prejudice, shame, domestic violence, lack of support from family members and/ or friends, and the fact that the partner did not assume the child. The prejudice on the part of the relatives was evidenced in the following statement: At school there was not so much prejudice, the greatest prejudice was at home. My mother ... she even threw me out of the house (Sálvia).

The prejudice that generated the shame was perceived in the following statements: The friends that we think are friends, at that time of the comment, stabbing. I did the first year of high school, I stopped in the middle of the year, I could not, I would go to school and the staff would talk, we would be ashamed (Rosa). At school, just those comments. They commented that I was pregnant ... It was embarrassing because everyone was watching and commenting that I was very young ... Then I gave up (Acácia).

Domestic violence was a factor declared by one of the interviewees: But only after I got pregnant, it complicated because my husband, because now he changed, but before when I was pregnant, he was very violent, he beat me a lot. At that time he wanted to kill the child, angry at home (Jasmin).

The lack of support from family and/or friends appears in several statements: She (mother) treated me ba$d l y$, as if I were the first person in the world to err (Salvia). It was quite heavy, see?! It was like this with the family, because I was the only daughter, the family did not accept, no ... (Silence. Patient is moved to remember and cries). It's difficult. It was quite complicated (the relationship with the mother). My brother, too, the friends at school, we get a bit puzzled (Rosa).

The fact that the partner did not assume the child was perceived as something that negatively impacted the moment the teenager lived his pregnancy:
...In the case of my son's father, he liked the news, but did not assume ... What's the use of liking and not assuming? For me it was bad because I stayed inside my mother's house. He did not respect me. It was such a very troubled pregnancy. He never even respected me. I do not even have contact. I know where he is, but he is not a good person, he was not a good person (Erica).

It is noteworthy that other factors that made the experience of teenage pregnancy difficult to understand, such as being young, loss of social life, difficulty in continuing the studies, and difficulty in finding a job after the birth of the child.

\section{Positive and Negative Pregnancy Repercussions in Adolescence under Women's Vision}

This category originated from the following question asked to the women: "What has the experience of having pregnancy in adolescence brought to your life today?"

Responsibility and maturity from the experience lived in adolescence were considered by the interviewees as positive aspects, because with the development of these qualities they could become better, more capable people: I learned to be responsible, to have a sense of things earlier, ripe earlier (Lavender). ... mature ahead of time. Because if I was not her mother at that age I would not be the person I am (Salvia).

Other aspects perceived by the interviewees as positive and with repercussions until the present day in their lives were: constitution of a family and union of the families; being a mother; being young to accompany the child's growth. One of the interviewees reported that to constitute a family was something that had a positive impact on her life: Positive was only to build the family, but I should have waited more (Acácia).

In Jasmin's interview, the positive aspect reported was the union between families: I had a quarrel with the family, his family with mine, but after I got pregnant, the family reunited, it was very good, and now everything is peaceful. The fact that she was a mother was mentioned in the interviewees' statements as positive, as can be seen in the following statements: ... It 
was my dream to have a child ... Although I was very young, as a teenager, I was very young... It was very good for me. It was planned, we both planned (Jasmin). Ah!!! to know that, in spite of everything, I managed to go until the end of the pregnancy, although many did not want to. Just looking at her like that ... it was worth it (Rosa).

Being a young mother was considered by one of the interviewees to be positive, since she could keep track of the child's growth for a longer time: ...Sometimes I stop and think like this: If I had had him at 20 years old, would I have had the happiness of seeing him reach 18? I was going to be at a much older age. I know I've seen him grow up, that I'm there, that I can accompany him even longer (Lavender).

Negative aspects were reported: no study completion; fear of having another child; responsibility; difficult to reach plans. The failure to complete the studies was perceived as harmful by the interviewees: I stopped the studies. I did not study. I did not graduate (Acacia).... it hurt my life more so because I did not finish my studies, it hurt more so. What I lack most today is my studies (Jasmin).

The responsibility was also perceived by the interviewees as negative: ...It became a little more difficult because in the place of people having to work to build for both of us, we had to build for three (Lavander). Responsibility for raising children has hampered the achievement of goals: It was already more difficult, a child always needs more than adults, it's more care, it's more expense, and it takes us a long time to build our house because we were like that... it was always them first ... for us to build a house, ... it was more difficult (Lavander).

The fear of having another child due to the experience of a child with dystocia was evidenced in the following passage: For me it was only at the time of childbirth ... it was very scary. It was a forceps birth ... I suffered our ... about eighteen hours or more. It was very, very complicated, he almost died ... it was like this ... it was my memory, I was very scared, and I did not have the courage to have another one (Dahlia).

\section{Rescuing knowledge about contraceptive methods in adolescence}

When asked if they knew and/or used a contraceptive method in adolescence, most reported that they did. Regarding its use, only one of the interviewe- es reported having used the pill during adolescence.

You can observe this in these statements: I knew, but I did not use it. He knew the pill and a condom (Jasmin). I knew it, did not I?! But I did not use ... the pill the condom ... but the very young people do not think about it! (Erica). The pill. I used two months. Then I left him, my boyfriend. It was only for one night that it happened (Sálvia).

Only one of the interviewees reported having no knowledge at the time about contraceptive methods and related this to the difficulty of accessing the health service. In the report of Lavender, the difficulty of access to the health service was also emphasized, being in this case associated with the age of the adolescent, because being a minor made it difficult for the acquisition of the contraceptive and caused embarrassment.

\section{Discussion}

This study had as a limitation the similar experiences of women considering that the socio-demographic profile of the interviewees was practically the same because they lived in the same community and experienced common life histories. This limitation is characteristic of the qualitative research that refers only to the world lived by the subject.

Many studies focus on teen pregnancy and the feelings experienced at this stage. The contribution of this study lies in the perspective of how the woman experienced challenges and difficulties until she reaches adulthood and how she analyzes this experience in a more mature stage of life. The practical applicability of this study is to provide subsidies for the production of coping strategies for teenage pregnancy, ways to continue studying and avoid an unplanned second pregnancy.

Experiencing a pregnancy in adolescence brought difficulties, causing adolescents to develop early responsibility and maturity. Teenage pregnancy was perceived in different ways by the women who experienced it. Some have considered motherhood during adolescence as a good thing, which has brought satis- 
faction and happiness, despite adversities, enabling maturation, family changes, and development of resilient factors, making teenage mothers responsible and aware of their roles ${ }^{(10)}$.

However, for other women, teenage motherhood had as a consequence the loss of social contact, dropping out of school, exclusion from the labor market due to lack of support for child care. It is perceived that the discovery of unplanned pregnancy can mean loss of youth and assimilation of great responsibilities, with pregnancy permeated by feelings of rejection, lack of support from the most significant persons for adolescents, fear of assuming pregnancy for the parents and/or boyfriend, sometimes leading the adolescent to choose to interrupt gestation ${ }^{(11)}$.

The role of the family strongly influences the protection of teenage pregnancy and the early onset of sexual activity. The strengths of the family at this stage of a woman's life are proximity and responsiveness to health care needs, feelings of support, loyalty, and feeling loved ${ }^{(12)}$.

The study showed that most of the women had less than nine years of schooling and did not exercise paid work, and the income of the household was provided by the partner, favoring the beginning of a cascade of exclusion. The woman's financial dependence on her husband, given her obligations to maintain the home and care for her children, helps her not to go back to school and is therefore not qualified for the job market, in order to improve her family's quality of life.

It is also worth outstanding that, in this condition as a teenage mother and responsible for the care of the children while the companion provides the unerated way, reproducing the cycle of poverty ${ }^{(13)}$.

An important issue highlighted in the study isupport of the home, the admission into the labor market can happen in an unspecialized and poorly rems the shame felt by the pregnant teenager in the school environment due to comments and prejudiced looks, with consequent dropout. During the interviews, it was noticed that some interviewees showed a desire to go back to school, while others did not. Liabilities with children, lack of support and/or self-interest are reported as factors impeding the search for return to school.

The shame felt by the adolescents and the fear of their peers' judgment are two factors that favored the dropout of the pregnant teenager. In this context, the representations that involved motherhood in adolescence may be related to social stereotypes that affect the self-esteem of adolescents and, in this way, are perceived with fear by them. In addition, negative feelings experienced by the school emerged as a factor that, together with the feeling of shame, contributed to school dropout ${ }^{(14)}$.

Regarding the repercussions of teenage pregnancy in their lives today, the interviewees pointed out positive and negative aspects. Responsibility proved to be something negative and also positive, which led to the development of maturity, making them different and more capable people, as if the girl had become a woman. The question of not completing the studies had negative repercussions according to the interviewees' speech, as the study was seen by some as a driver of a better future.

As to the knowledge about contraceptive methods, it was verified that they were limited to oral contraceptives and male condoms only. This may be related to the lack of information in the sense of empowering the individual and the difficulty of access to other forms of contraception. Lack of knowledge about contraceptive methods and/or inappropriate use of contraceptive methods have contributed significantly to a teenage pregnancy ${ }^{(15)}$.

Investments in contraceptive technology, which include the appropriate input and adequate information on the dosage of contraceptive methods, should be encouraged under the logic of reducing costs to the health system due to unwanted pregnancies and the risk of induced abortions ${ }^{(16)}$.

Adolescent motherhood cannot continue to be perceived in a stigmatizing way in the attention of health professionals, considering that adolescents have the right to a sexual life, making their own decisions 
consciously and based on adequate knowledge. However, for this to happen, health professionals must act by implementing ad hoc health policies, ensuring access to health services, health education and contraceptive methods ${ }^{(17)}$.

The current model of assistance to adolescent pregnant women should be reformulated, seeking action strategies aimed at adolescents and their coexistence groups, thus ensuring a comprehensive and continuous care that provides means for the adolescent to fully and satisfactorily reach adulthood ${ }^{(11)}$.

The adolescent should also be encouraged to become an active subject of care. The meaning that each adolescent attributes to health knowledge and practices is a decisive factor for decision-making in relation to self-care ${ }^{(18)}$.

\section{Conclusion}

The results showed that women who had a teenage pregnancy, had low schooling, had informal employment or did not work, taking responsibility for the home and children. In adolescence, most of the women interviewed knew only the condom and/or oral contraceptive as contraceptive methods and did not use them because of lack of access or belief and myths.

The pregnancy occurred during adolescence had a positive and negative impact on the woman's life. Some positive aspects reported were: the development of responsibility and maturity, the constitution of a family and the experience of being a mother. As for the negative aspects, the following issues were reported: the abandonment of studies; the fear of having another child; responsibility; and the difficulty to reach plans for the future.

\section{Collaborations}

Dias PMM contributed in designing the project, collecting, analyzing and interpreting the data and writing of the article. Lustosa AP and Lima HKLS con- tributed in the analysis and interpretation of the data. Oliveira JM, Moreira KAP and Pereira TM contributed to the relevant critical analysis of the content, writing of article and final approval of the version to be published.

\section{References}

1. World Health Organization. Adolescent hearth [Internet]. 2008 [cited 2015 Feb 20]. Available from:http://www.who.int/topics/adolescent_ health/en/

2. Instituto Brasileiro de Geografia e Estatística (BR). Estimativas da população residente no Brasil e Unidades da Federação [Internet]. 2016 [citado 2017 jan 06]. Disponível em: www.ftp.ibge.gov. br/Estimativas_de_Populacao/Estimativas_2016/ estimativa_dou_2016_20160913.pdf

3. Queiroga KRO, Farias MCAD, Casimiro GS, Nascimento ARS, Maia PCGGS, Abrantes KSM, et al. What is and how can be explained pregnancy in adolescence. Rev Bras Crescimento Desenvolv Hum [Internet]. 2014 [citado 2015 fev 20]; 24(2):142-9. Disponível em: http://pepsic. bvsalud.org/pdf/rbcdh/v24n2/pt_04.pdf

4. Instituto Brasileiro de Geografia e Estatística (BR). Estudos \& Pesquisas. Informação, demográfica e socioeconômica n.33. Estatística de gêneros. Uma análise dos resultados do Censo Demográfico 2010. Rio de Janeiro: IBGE; 2014.

5. Ministério da Saúde (BR). Sistema de Informações sobre Nascidos Vivos - SINASC - Dados preliminares [Internet]. 2014 [citado 2017 jan 04]. Disponível em: http://www2.datasus.gov.br/ DATASUS/index.php

6. Nery IS, Gouveia MTO. Gravidez na adolescência: limites e possibilidades da prevenção com ênfase no cuidado de enfermagem. In: Souza KV, Duarte ED, Morais SCRV, organizadores. Associação Brasileira de Obstetrizes e Enfermeiros Obstetras. PROENF Programa de Atualização em Enfermagem: saúde materna e neonatal: Ciclo 5. Porto Alegre: Artmed/Panamericana; 2013. p.9-39.

7. Polit DF, Beck CT, Hungler BP. Fundamentos de pesquisa em enfermagem: métodos, avaliação e utilização. Porto Alegre: Artmed; 2011. 
8. Fontanella BJB, Luchesi BM, Saidel MGB, Ricas J, Turato ER, Melo DG. Amostragem em pesquisas qualitativas: proposta de procedimentos para constatar saturação teórica. Cad Saúde Pública. 2011; 27(2):389-94.

9. Bardin L. Análise de conteúdo. São Paulo: Edições 70; 2011.

10. Ribeiro PM, Gualda DMR. Gestação na adolescência; a construção do processo saúderesiliência. Esc Anna Nery. 2011; 15 (2):361-71.

11. Paixão GPN, Gomes NP, Morais AC, Camargo CL. Decovering pregnant: teenage experiences. Cienc Cuid Saúde. 2014; 13(3):418-24.

12. Hillis SD, Anda RF, Dube SR, Felitti VJ, Marchbanks PA, Macaluso $\mathrm{M}$, et al. The protective effect of family strengths in childhood against adolescent pregnancy and its long-term psychosocial consequences. Perm J. 2010; 14(3):18-27.

13. Caminha NO, Costa CC, Brasil RFG, Sousa DMN, Freitas LV, Damasceno AKC. O perfil das puérperas adolescentes atendidas em uma maternidade de referência de Fortaleza-Ceará. Esc Anna Nery. 2012; 16(3):486-92.
14. Santos CC, Cremonese L, Wilhelm LA, Castiglioni CM, Ressel LB. Perfil social de adolescentes gestantes e abandono escolar. Adolesc Saúde. 2014; 11(3):71-6.

15. Queiroz MVO, Brasil EGM, Alcântara CM, Carneiro, MGO. Profile of pregnancy in adolescence and related clinical-obstetric occurrences. Rev Rene. 2014; 15(3):455-62.

16. Darroch JE, Woog V, Bankole A, Ashford LS. Adding It Up: Costs and benefits of meeting the contraceptive needs of adolescentes. Guttmacher Institute. [Internet]. 2016 [cited 2016 Feb 20]; 1-15. Available from: https://www.guttmacher. org/sites/default/files/report_pdf/adding-it-upadolescents-report.pdf

17. Souza ZAA, Silva JG, Ferreira MA. Saberes e práticas de adolescentes sobre saúde: implicações para o estilo de vida e cuidado de si. Esc Anna Nery. 2014; 18(3):400-6.

18. Santos CC, Castiglioni CM, Cremonese L, Wilhelm LA, Ressel LB. Expectations of pregnant teens for the future. J Res Fundam Care Online [Internet]. 2014 [cited 2016 Feb 20]; 6(2):759-66. Available from:http://www.seer.unirio.br/index.php/ cuidadofundamental/article/view/3110 